\title{
Chapter 14 \\ Modulation of Host Cell Death by SARS Coronavirus Proteins
}

\author{
Claudia Diemer, Martha Schneider, Hermann M. Schätzl, and Sabine Gilch
}

\begin{abstract}
Both types of cell death, namely necrosis and apoptosis, are found in organs of SARS coronavirus $(\mathrm{CoV})$ infected patients. The gastrointestinal tract, however, although also a target for SARS-CoV replication, is obviously not affected by cell death mechanisms. Such differences in cell death induction are paralleled by in-vitro studies. In a colon-derived cell line (Caco-2), proapoptotic proteins were down- and antiapoptotic proteins were upregulated during SARS$\mathrm{CoV}$ infection. By contrast, in SARS-CoV infected Vero E6 cells, apoptosis was induced via the p38 MAPK and caspase dependent pathways. Both apoptotic pathways, although mostly the intrinsic signal transduction, can be targeted by structural as well as accessory proteins of SARS-CoV. The fact that all structural and most of the accessory proteins of SARS-CoV are implicated in apoptotic scenarios indicates the fundamental role of apoptosis in the SARS-CoV life cycle. Interestingly, at least for the nucleocapsid protein of SARS-CoV, a celltype specific manipulation of apoptosis was confirmed.
\end{abstract}

\subsection{Cell Death During SARS-CoV Infection}

SARS manifests predominantly as a viral pneumonia with diffuse alveolar damage. Although the exact mechanisms of SARS pathogenesis are not known, the lung damage in patients with SARS appears to be due to apoptosis and necrosis, both induced directly by viral replication as well as indirectly by production of immune mediators. SARS-CoV has also been found in various extrapulmonary tissues. Infected tissues from autopsied or biopsied SARS-CoV patients, varying in histopathological findings with regard to necrosis, apoptosis or no tissue damage, are

H.M. Schätzl ( $($ )

Institute of Virology, Technische Universität München, Trogerstr. 30, 81675 Munich, Germany

e-mail: schaetzl@virologie.med.tum.de 
summarized in Table 14.1 (Guo et al. 2008; Zhang et al. 2003). Whereas apoptosisand/or necrosis-induced tissue damage is found in various SARS-CoV infected organs such as lung, liver, brain, and immune cells, SARS-CoV replication in the gastrointestinal tract apparently does not cause histopathological changes.

Moreover, differences of SARS-CoV pathology in infected organs are paralleled by in-vitro studies employing SARS-CoV infected cell lines. It was reported that SARS-CoV infection of Vero E6 (African green monkey kidney) cells induces apoptosis via the p38 MAPK and caspase dependent pathways (Bordi et al. 2006; Mizutani et al. 2004b; Ren et al. 2005; Yan et al. 2004). By contrast, in SARS-CoV infected Caco-2 cells (colon carcinoma), proapoptotic proteins were down- and antiapoptotic factors were upregulated (Cinatl et al. 2004). These data indicate that the modulation of apoptosis by SARS-CoV seems to be crucial for the cell-type specific phenotype of infection and might subsequently account for the differences of SARS-CoV pathology. Notably, no induction of necrosis was observed in SARS$\mathrm{CoV}$ infected cell lines. Necrosis is frequently induced by immunological mediators and is characterized as nongenetically regulated cell death. Apoptosis, in contrast, is genetically highly regulated and the molecular mechanism is classically divided into two major apoptotic pathways (Green 2000), called extrinsic and intrinsic pathway. Extrinsic signals are transmitted by members of the tumor necrosis factor (TNF) superfamiliy. Ligand binding to TNF family death receptors recruits adaptors and initiator procaspases-8 and/or -10 to form the death-inducing signaling complex (DISC). The DISC formation results in the autocatalytic activation of initiator caspases. Once initiator caspases are activated they directly cleave effector caspases $(3,6,7)$ to convert them into their active form. Now effector caspases are able to degrade their targets such as cytoskeletal proteins or nuclear lamins to facilitate cell death.

Intrinsic signals are propagated to mitochondria by the $\mathrm{Bcl}-2$ protein family. There are pro-survival members of this family (Bcl-2, Bcl-xL, Bcl-w, Mcl-1,

Table 14.1 Organs and cell types infected by SARS-CoV

\begin{tabular}{|c|c|c|c|c|c|c|}
\hline & \multicolumn{6}{|c|}{ Organs } \\
\hline & Lung & Kidney & Liver & Brain & Intestine & $\begin{array}{l}\text { Immune } \\
\text { system }\end{array}$ \\
\hline $\begin{array}{l}\text { Detection } \\
\text { of SARS- } \\
\text { CoV }\end{array}$ & $\begin{array}{l}\text { ISH, EM, } \\
\text { RT-PCR }\end{array}$ & ISH, EM & RT-PCR & $\begin{array}{l}\text { EM, } \\
\text { RT-PCR }\end{array}$ & $\begin{array}{l}\text { ISH, EM, } \\
\text { RT-PCR }\end{array}$ & EM, ISH \\
\hline Cell types & $\begin{array}{l}\text { Pneumocyte, } \\
\text { endothelial } \\
\text { and epithelial } \\
\text { cells, } \\
\text { macrophage, } \\
\text { lymphocyte }\end{array}$ & $\begin{array}{c}\text { Epithelial } \\
\text { cells of } \\
\text { renal } \\
\text { tubules }\end{array}$ & Hepatocyte & $\begin{array}{l}\text { Neurons of } \\
\text { cortex and } \\
\text { hypothalamus }\end{array}$ & $\begin{array}{r}\text { Epithelial } \\
\text { cells of } \\
\text { mucosa }\end{array}$ & $\begin{array}{l}\text { Monocyte, } \\
\text { lymphocyte, } \\
\text { macrophage } \\
\text { in lymph } \\
\text { node, spleen }\end{array}$ \\
\hline $\begin{array}{l}\text { Tissue } \\
\text { damage }\end{array}$ & + & + & + & + & - & + \\
\hline Cell death & $\begin{array}{r}\text { Apoptosis, } \\
\text { necrosis }\end{array}$ & Necrosis & Apoptosis & Necrosis & $\begin{array}{l}\text { No tissue } \\
\text { damage }\end{array}$ & Necrosis \\
\hline
\end{tabular}

+ positive; - negative; ISH: In situ hybridization; RT-PCR: Reverse-transcription polymerase chain reaction; EM: Electronic microscopy 
and A1) which oppose proapoptotic members (Bax, Bak, Bok, Bad, Bid, Bik, Puma, and Noxa). Moreover, cross-talk between the intrinsic and extrinsic pathway exists by caspase- 8 mediated cleavage of Bid. The intrinsic pathway is highly regulated by the interactions of pro- and antiapoptotic Bcl-2 proteins. Monitoring of intrinsic signals leads, for example, to binding of Bad to the pro-survival Bcl-2 proteins and results in release of Bax and Bak from these proteins. Once Bax and Bak are released they oligomerize and insert into the mitochondrial membrane causing an efflux of cytochrome $c$. Cytochrome $c$ oligomerizes with Apaf1 and recruits initiator procaspase-9 to form the apoptosome, finally resulting in proteolytic activation of caspase9. Caspase- 9 then initiates the caspase cascade by cleaving effector caspases $(3,6,7)$ which subsequently degrade their target proteins.

A counterpart to the intrinsic apoptotic pathway is the pro-survival PI3K-Akt signal transduction. PI3K activates several downstream effectors such as the serine-threonine kinase Akt which regulates cell growth, cell cycle and cell survival (Cantrell 2001). Activated Akt phosphorylates a number of proapoptotic proteins including Bad and caspase-9. Thereby, the proapoptotic proteins are inactivated (Kulik et al. 1997). Similar to several other viruses, SARS-CoV also promotes PI3K-Akt signal transduction to establish persistent infection in Vero cell lines (Mizutani et al. 2005). Moreover it was shown that the activation of PI3K-Akt is differentiation state-specific in intestinal cells (Gauthier et al. 2001) and inhibits FAS-induced apoptosis in human intestinal epithelial cells (Abreu et al. 2001). In several studies it was shown that SARS-CoV can both induce and inhibit apoptosis in a cell-type specific manner. Activation of PI3K-Akt signal transduction in specific cell lines could offer an explanation; the mechanism for cell-type specific modulation of apoptosis, however, needs to be elucidated. Although it was shown by over-expression of Bcl-2 (Bordi et al. 2006) or by treatment with caspase inhibitors (Ren et al. 2005) that induction of apoptosis by SARS-CoV does not favor viral replication, SARS-CoV might induce apoptosis upon effective replication, potentially to evade immune response or to enable spread to other target organs. Alternatively, SARS-CoV may establish persistent infection by inhibition of apoptosis in cell lines derived from the intestine.

In summary, these data indicate a host cell specific modulation of cell death by SARS-CoV and an important role of apoptosis in SARS-CoV pathogenesis. Although the role of apoptosis for the severe clinical outcome of SARS-CoV infection is not entirely clear, the fact that all structural proteins and several of the accessory proteins investigated so far can induce apoptosis indicates that apoptotic cell death is important for the SARS-CoV life-cycle.

\subsection{Induction of Host Cell Death by SARS-CoV Structural Proteins}

The SARS-CoV virion consists of four main structural proteins, namely the nucleocapid $(\mathrm{N})$, envelope $(\mathrm{E})$, membrane $(\mathrm{M})$, and spike $(\mathrm{S})$ proteins. $\mathrm{N}$ provides the structural basis for the helical nucleocapsid by complexing the viral RNA 
genome. The nucleocapsid is surrounded by an envelope containing the other three structural proteins E, S and M. Beside the primary functions of the structural proteins, namely to constitute the virion scaffold and to execute viral morphogenesis, these proteins also modulate host cell death pathways such as apoptosis.

\subsubsection{E Protein}

Similar to the E protein of murine hepatitis virus (MHV), SARS-CoV E can induce apoptosis under certain conditions. It was demonstrated that adenoviral-mediated over-expression of $\mathrm{E}$ promotes cell death in the human T-cell line Jurkat upon serum deprivation (Yang et al. 2005). In contrast, Vero E6 viability was not affected by E over-expression (Chow et al. 2005); however, in this study cells were cultivated in the presence of growth factors and the role of starvation was not addressed. It is of particular interest that T-cell death can be induced by a structural protein of SARS-CoV, since lymphopenia is one clinical hallmark of patients suffering from SARS that occurs in up to $100 \%$ of the patients (Booth et al. 2003; Yang et al. 2004). Thus, expression of $E$ in infected lymphocytes could contribute to this remarkable cell death. On the molecular level, E induces cell death by sequestering the antiapoptotic Bcl-xL protein to ER membranes (Yang et al. 2005), thereby probably preventing its incorporation into the mitochondrial membrane. Consequently, over-expression of Bcl-xL attenuates the proapoptotic effect of E (Yang et al. 2005). Interestingly, in Vero E6 cells infected with SARS$\mathrm{CoV}$ apoptosis can also be prevented by over-expression of Bcl-2 (Bordi et al. 2006).

\subsubsection{Protein}

The intrinsic apoptotic pathway is also activated by the $\mathrm{M}$ protein. Initially, induction of apoptosis was shown in the absence of growth factors in human pulmonary fibroblast (HPF) cells. In these cells apoptosis was also induced by $\mathrm{N}$ over-expression. In contrast, using a baculoviral expression system in insect cells, only M but not $\mathrm{N}$ expression led to cell death (Lai et al. 2006). Upon co-expression of $\mathrm{M}$ and $\mathrm{N}$ in serum-depleted HPF cells, apoptosis was increased compared to cultures expressing either $\mathrm{M}$ or $\mathrm{N}$ alone (Zhao et al. 2006). This could be due to the observed interaction between these two structural proteins (He et al. 2004). Furthermore, HEK293 cells and a Drosophila model over-expressing M exhibited an apoptotic phenotype (Chan et al. 2007). M expression in HEK293 cells induced cytochrome $c$ release (Chan et al. 2007), leading to activation of the intrinsic apoptotic pathway. In addition, serine phosphorylation of Akt was reduced in HEK cells expressing $M$, indicating that the transduction of survival signals could 
be prevented thereby. This is in line with alterations observed in SARS-CoV infected Vero E6 cells (Mizutani et al. 2004a). Here, Akt was dephosphorylated $18 \mathrm{~h}$ postinfection (p.i.). At this time point of infection, $\mathrm{M}$ is detectable in SARSCoV infected Vero E6 cells (Mizutani et al. 2004b), and it might be possible that M expression leads to Akt dephosphorylation.

\subsubsection{S Protein}

Vero E6 cells were employed to study the proapoptotic potential of the SARS-CoV structural proteins upon adenoviral expression (Chow et al. 2005). In this experimental set-up, apoptosis could only be activated by $\mathrm{S}$, in particular the $\mathrm{S} 2$ domain (Chow et al. 2005). Induction of apoptosis by $\mathrm{S}$ appears to be unique for SARS-CoV S since neither MHV (An et al. 1999) nor infectious bronchitis virus (IBV) (Liu et al. 2001) S proteins induced apoptosis. In a follow-up study, microarray analysis of S2-transduced Vero E6 cells was performed (Yeung et al. 2008). Here, expressions of several genes involved in the extrinsic apoptotic pathway were downregulated, whereas the upregulation of CYCS and of Mdm-2 involved in the regulation of p53 degradation provides a hint to an activation of the intrinsic apoptotic pathway. The antiapoptotic proteins $\mathrm{Mcl}-1, \mathrm{Bcl}-\mathrm{xL}$ and $\mathrm{Bcl}-2$ were downregulated by $\mathrm{S} 2$ over-expression (Yeung et al. 2008), in line with a downregulation of Bcl-2 in SARS-CoV infected Vero E6 cells (Ren et al. 2005). However, in contrast to infected cells (Mizutani et al. 2004b), components of the MAPK pathway were also downregulated (Yeung et al. 2008). Since $S$ expression triggers ER stress response (Chan et al. 2006), prolonged ER stress in S expressing cells might finally lead to apoptotic cell death.

\subsubsection{N Protein}

The most compelling evidence for the proapoptotic potential of SARS-CoV structural proteins is provided for the $\mathrm{N}$ protein. Several studies performed by different groups indicated that $\mathrm{N}$ leads to apoptotic cell death in the absence of growth factors in COS-1 (Surjit et al. 2004; Zhang et al. 2007), HPF (Zhao et al. 2006), or in Vero E6 and A549 (human lung carcinoma) cells, but not Caco-2 (human colon carcinoma) or N2a (murine neuroblastoma) cells (Diemer et al. 2008). In addition, the human hepatoma cell lines Hep-G2 (Zhang et al. 2007) and Huh-7 (Surjit et al. 2004; Zhang et al. 2007) did not undergo apoptosis upon N expression. In COS-1 cells, induction of apoptosis was independent of Bax and p53. Bcl-2 expression as well as Akt phosphorylation were reduced, whereas the MAPK pathway and caspases were activated. It was speculated that apoptosis was initiated via an integrin dependent pathway (Surjit et al. 2004). In addition, mitochondrial cytochrome $c$ release was observed (Zhang et al. 2007). Interestingly, N-induced 
apoptosis appears to be cell-type specific and among the investigated cell lines only COS-1, Vero E6 and A549 clearly exhibited apoptosis (Diemer et al. 2008; Surjit et al. 2004; Zhang et al. 2007). The fact that A549 cells, which are similar to Caco2 and Huh-7 cells derived from a carcinoma, undergo apoptosis, argues against an artificial effect of cell-type specificity due to different immortalization protocols, as discussed by Surjit et al. (2004) for Huh-7 and COS-1. Diemer et al. (2008) demonstrated that upon $\mathrm{N}$ over-expression and SARS-CoV infection $\mathrm{N}$ acts not only as an inducer but finally also as a substrate of effector caspases. The significance of this finding is supported by a proteomics approach, by which $\mathrm{N}$ also was identified to be a substrate of caspases-3 and -6 (Ying et al. 2004). Interestingly, the $\mathrm{N}$ cleavage by caspases indicative for the induction of apoptosis correlated with the localization of $\mathrm{N}$ to the nucleus and the efficiency of viral replication (Diemer et al. 2008). In Vero E6 cells $N$ was partially located to the nucleus, cleaved by caspases and high viral titers were produced. By contrast, in Caco- 2 cells $\mathrm{N}$ was located only in the cytoplasm, was not cleaved and virus production was about 100 -fold lower than in Vero E6 cells. Furthermore, activation of the proapoptotic protein Bad correlated with the nuclear localization of $\mathrm{N}$. Thus, nuclear localization of $\mathrm{N}$ appears to be a factor that critically influences induction of apoptosis via the intrinsic pathway and there might also be a correlation with the replication efficiency (Diemer et al. 2008; illustrated in Fig. 14.1).

Furthermore, TGF- $\beta$ (transforming growth factor beta) signaling which plays a pivotal role in cell growth, differentiation, apoptosis, and tissue remodeling is affected by $\mathrm{N}$ expression. In TGF- $\beta$ stimulated cells, binding of $\mathrm{N}$ to Smad3, a downstream target of the TGF- $\beta$ signaling pathway, promoted Smad3-p300 complex formation. Thereby, Smad3/Smad4 heterocomplex formation which leads to induction of apoptosis was inhibited. This was observed in HEK293, MEF and human peripheral lung epithelial (HPL1) cells (Zhao et al. 2008). The interaction of $\mathrm{N}$ and Smad3 was able to compete for the nuclear localization of $\mathrm{N}$, resulting in attenuation of apoptosis, and could therefore describe a control mechanism of cell death during SARS-CoV infection. The observed interference of $\mathrm{N}$ expression with TGF- $\beta$ signaling on the one hand inhibits apoptosis, and on the other hand increases the expression of plasminogen activator inhibitor-1 (PAI-1) which promotes fibrosis. This provides an interesting molecular link to the lung pathology observed in SARS patients, since pulmonary fibrosis is associated with lung failure (Nicholls et al. 2003, 2006).

\subsection{Accessory Proteins}

The SARS-CoV genome harbors at the $3^{\prime}$ end some unique, group-specific genes which encode the eight putative accessory proteins $3 a, 3 b, 6,7 a, 7 b, 8 a, 8 b$, and $9 b$ (Marra et al. 2003). Their exact contributions to viral replication or pathogenesis in the natural host have not been entirely elucidated. Yount et al. have demonstrated that the deletion of SARS-CoV ORF3a, 3b, 6, 7a, and 7b did not dramatically 


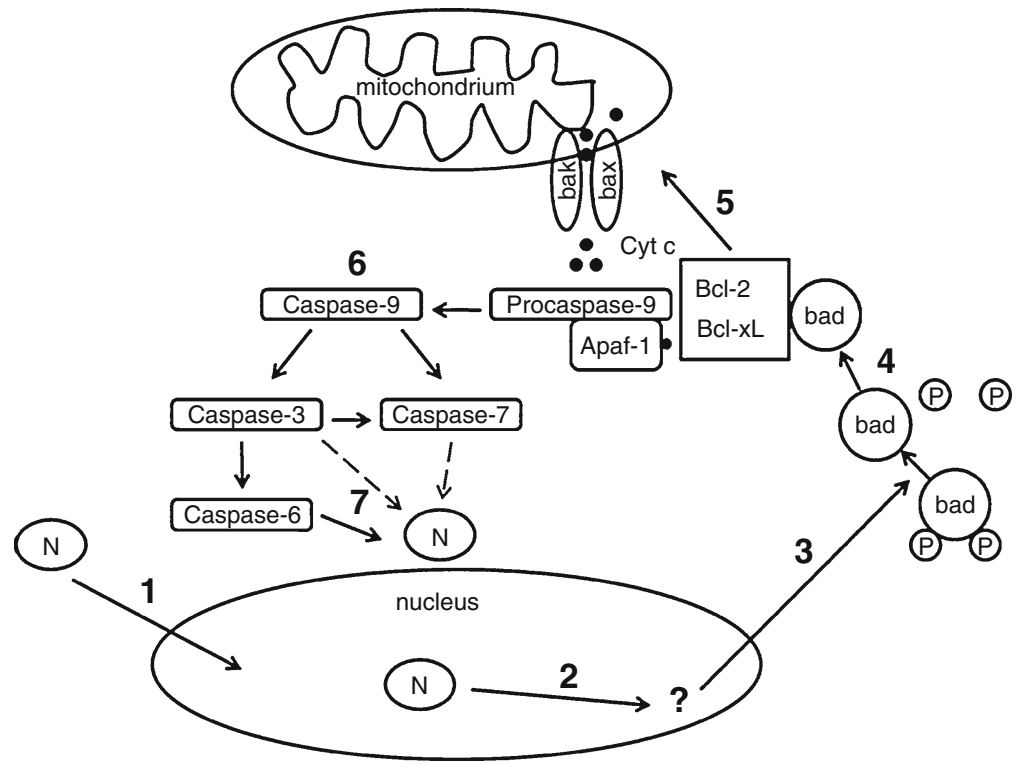

Fig. 14.1 Hypothetical model for correlation of nuclear localization and caspase-mediated cleavage of N in lytic SARS-CoV infection (adapted from Diemer et al. 2008). N translocates into the nucleus (1) and may activate gene expression or interact with nuclear components there (2), resulting in the dephosphorylation of $\mathrm{Bad}(3)$. In this form Bad is enabled to interact with Bcl-2 and $\mathrm{Bcl}-\mathrm{xL}$ (4). This interaction releases Bax and Bak from pro-survival Bcl-2 proteins, enabling insertion of Bax and Bak in the mitochondrial membrane. The resulting membrane permeabilization facilitates cytochrome $c$ efflux (5) which provokes the activation of procaspase-9 by formation of apoptosome. Once caspase- 9 is activated the caspase cascade occurs and effector caspases (i.e., 3,6 , and 7) are activated (6). Finally, $\mathrm{N}$ is cleaved by caspase-6 (7), but cleavage of $\mathrm{N}$ may additionally be caused by caspase- 3 or -7

influence replication efficiencies in cell culture or in a murine model of SARS$\mathrm{CoV}$ infection. However, in the same study it was observed that upon deletion of ORF3a, virus titers were reduced to a certain degree (Yount et al. 2005). Akerström et al. also observed a significant reduction in the yield of progeny virus when Vero E6 cells expressing siRNA against ORF3 or 7 were infected with SARS-CoV (Akerstrom et al. 2007). Even if the applied siRNAs caused knockdown of the complete ORF3, ORF7 and ORF8, encoding for 3a, 3b, 7a, 7b, 8a, and 8b proteins, respectively, a partial participation in viral replication cannot be excluded for some of them. In addition, over-expression of the 8a protein in infected Vero E6 cells can enhance viral replication and, in infected HuH-7 cells, virus-mediated cytopathic effects (Chen et al. 2007). As the mechanisms of viral pathogenesis are still unclear, the ability of accessory proteins to modulate cell death is of special interest. 


\subsubsection{Protein $3 a$}

The largest of the accessory proteins consists of 274 amino acids and is expressed in transfected (Huang et al. 2006b; Law et al. 2005; Tan et al. 2005; Yuan et al. 2005a) and infected cells (Lu et al. 2006; Yu et al. 2004; Zeng et al. 2004). In both cases the protein was shown to be associated with intracellular membranes and the plasma membrane (Ito et al. 2005; Tan et al. 2004b; Yuan et al. 2005a), to be released into the surrounding media (Huang et al. 2006b), and it appears to be a structural protein of the SARS-CoV (Ito et al. 2005; Shen et al. 2005). By transient expression in Vero E6 cells, 3a induced the extrinsic apoptotic pathway via caspase-8, whereas no induction of the intrinsic apoptotic pathway could be observed (Law et al. 2005). However, Padhan et al. demonstrated that protein 3 a additionally can activate the intrinsic apoptotic pathway. Although activation of caspase- 8 was confirmed, activation of caspase- 9 and increased Bax-oligomerization, characteristic for the intrinsic apoptotic pathway, were demonstrated. Treatment of transfected cells with a p38 MAPK inhibitor decreased the level of 3a-induced apoptosis, indicating upstream activation of p38 MAPK. Protein 3a seems to be potently proapoptotic as it is apparently able to induce and link both apoptotic pathways, as cleavage of Bid was also detected (Padhan et al. 2008). Although apoptosis can be the result of p38 MAPK activation, there exist alternative ways for the induction of apoptosis by protein 3a. Transient over-expression in HEK293, Cos-7, and Vero E6 cells led to decreased levels of cyclin D3 protein and mRNA, resulting in growth inhibition and cell cycle arrest at the G0/G1 phase (Yuan et al. 2007). Subsequently, apoptosis was induced to eliminate these cells. Additionally, the induction of the ER stressinducible proapoptotic kinase JNK by transient expression of 3a in HEK293 cells might lead to apoptosis (Kanzawa et al. 2006).

\subsubsection{Protein $3 b$}

Protein $3 \mathrm{~b}$ was shown to be expressed upon transient transfection in several cell lines (Khan et al. 2006; Kopecky-Bromberg et al. 2007; Yuan et al. 2005b) with a predominant nucleolar localization (Yuan et al. 2005c). In infected Vero E6 cells the protein could be detected also in the cytoplasm (Chan et al. 2005) and protein $3 \mathrm{~b}$ is likely to be expressed during infection in vivo. In Cos-7 and Vero E6 cells, overexpression of protein 3b caused apoptosis (Yuan et al. 2005b; Khan et al. 2006). As seen for protein $3 a$, transient over-expression of $3 b$ deregulates cell cycle progression of Cos-7, HEK293 and Vero E6 cells and causes growth inhibition and cell cycle arrest at the G0/G1 phase. Whereas the induction of cell cycle arrest was comparable in all used cell lines, the ability to induce apoptosis was significant in Cos-7 cells, but almost undetectable in HEK293 and Vero E6 cells (Yuan et al. 2005b). In addition, when Vero E6 cells were transiently transfected with protein 3b, increased levels of lactate dehydrogenase (LDH), a key marker of cells undergoing 
necrosis, were released. Therefore, the authors concluded that the accessory protein $3 \mathrm{~b}$ is able to induce necrosis (Khan et al. 2006).

\subsubsection{Protein 6}

ORF6 encodes a small 63-residue protein which is expressed upon transient transfection in several cell lines. It was also detected in infected Caco-2 and Vero E6 cells and in SARS patients. It localizes to the ER or Golgi membranes and to a perinuclear region (Frieman et al. 2007; Geng et al. 2005; Huang et al. 2007; Kopecky-Bromberg et al. 2007; Pewe et al. 2005). Furthermore, it was found incorporated into virus particles and is released from transfected and infected cells (Huang et al. 2007). Recently, it was shown that protein 6 is able to induce apoptosis in several cell lines, e.g., Cos-7, HEK293, and Vero E6, via a caspase-3 dependent pathway (Ye et al. 2008). However, the mechanisms leading to apoptosis are unclear.

\subsubsection{Protein $7 a$}

Protein 7a consists of 122 amino acids and is probably the best studied SARS-CoV accessory protein. It was the first accessory protein for which proapoptotic abilities were demonstrated (Tan et al. 2004a). In several transfected as well as infected cell lines, expression of 7a was confirmed (Fielding et al. 2004; Kanzawa et al. 2006; Kopecky-Bromberg et al. 2006; Nelson et al. 2005; Tan et al. 2004a; Yuan et al. 2006). Notably, it was detected in lung tissues from SARS-CoV infected patients (Chen et al. 2005). Protein 7a also appears to be a structural component of the virion (Huang et al. 2006a). With regard to the cellular localization, discrepancies exist as to whether it localizes to the ER, the ER-Golgi intermediate compartment, or the trans-Golgi network (Fielding et al. 2004; Kopecky-Bromberg et al. 2006; Nelson et al. 2005). Tan et al. however proposed that it is synthesized in the ER and shuttles rapidly to the Golgi or to mitochondria (Tan et al. 2007). The induction of apoptosis by $7 \mathrm{a}$ has been observed in several studies (Kopecky-

Bromberg et al. 2006; Tan et al. 2004a, 2007; Yuan et al. 2006). Its proapoptotic properties appear to be common for many cell types as over-expression of $7 \mathrm{a}$ induced the apoptotic pathway in cell lines originating from different tissues such as lung (A549 cell line), kidney (Cos-7, Vero E6, HEK293), cervix (HeLa), and liver (Hep-G2) (Tan et al. 2004a). Moreover, contribution to the modulation of apoptosis in the viral context has been confirmed. (Schaecher et al. 2007) demonstrated that a recombinant virus with deletion of ORF7a did not show alterations in replication kinetics or viral progeny but the mode of DNA fragmentation induced in infected Vero E6 cells was significantly altered as compared to cells infected with the wildtype virus. Furthermore, in this study a population of SARS-CoV infected cells 
which exhibited DNA fragmentation but no active caspase-3 was observed at $48 \mathrm{~h}$ and $72 \mathrm{~h}$ postinfection. This population was not detected if cells were infected with the respective ORF7a deletion mutant. Therefore, these cells might represent a population in a late stage of apoptosis in which active caspase- 3 is undetectable or, as DNA fragmentation can also be observed during necrosis, might alternatively represent a population of necrotic cells (Schaecher et al. 2007). The induction of cell cycle arrest at the G0/G1 phase appears to be a common feature of several accessory proteins and it was shown that transient over-expression of 7a in HEK293, Cos-7, and Vero E6 cells resulted in a deregulated cell cycle (Yuan et al. 2006). KopeckyBromberg et al. observed growth inhibition of 7a-expressing HEK293 cells and demonstrated that 7 a blocks gene expression at the level of translation. The influences of $7 \mathrm{a}$ on the host translation machinery together with induction of cell cycle arrest in G0/G1 phase could subsequently activate apoptosis. Despite activation of p38 MAPK, the inhibition of this kinase could not block induction of apoptosis (Kopecky-Bromberg et al. 2006). Whereas in this study no activation of JNK was found, Kanzawa et al. showed the activation of JNK in HEK293 cells overexpressing 7a (Kanzawa et al. 2006). These discrepancies concerning involved mediators or effectors imply that the protein 7 a probably uses alternative or several ways to induce apoptosis. Tan et al. recently demonstrated that $7 \mathrm{a}$ induces cell death by directly interacting with the antiapoptotic $\mathrm{Bcl}-\mathrm{xL}$, thereby preventing the interaction with proapoptotic Bcl-2 proteins. Consequently, 7a-induced apoptosis could be abrogated by over-expression of Bcl-xL (Tan et al. 2007). A further hint for the putative role of $7 \mathrm{a}$ in cell death scenarios was recently obtained in yeast-2-hybrid screens in which the proteins BiP and Bik were found as interactors of 7a (Diemer, Schneider, Schätzl and Gilch, personal communication).

\subsubsection{Proteins $8 a / 8 b$}

ORFs $8 \mathrm{a}$ and $8 \mathrm{~b}$ emerged at late stages of the SARS-CoV epidemic by a 29-nt deletion in the single ORF8 (Guan et al. 2003). The cytoplasmic expression of both accessory proteins was confirmed in virus-infected Vero E6 cells (Keng et al. 2006) and transfected cells (Chen et al. 2007; Law et al. 2006). Protein 8a mainly localizes to the cytoplasm or mitochondrial membranes of transfected HEK293 cells (Chen et al. 2007; Keng et al. 2006), whereas for 8b only a cytoplasmic localization was reported (Chen et al. 2007; Keng et al. 2006). Transient expression of 8a leads to induction of apoptosis in Huh-7 cells in a caspase-3 dependent way. In stably transfected Huh-7 cells, Chen et al. observed an enhanced production of reactive oxygen species (ROS), an increase of cellular oxygen consumption, and a hyperpolarization of the mitochondrial membrane. As the mitochondrial homeostasis is of special importance for induction of the intrinsic apoptotic pathway and consequently for cell survival, these changes might lead to apoptosis (Chen et al. 2007). However, accessory proteins are not always proapoptotic, they can also show antiapoptotic abilities. Along this line, Keng et al. demonstrated that the 
protein level of E was significantly decreased in Vero E6 cells cotransfected with SARS-CoV E and 8b. As the E protein is able to induce apoptosis in T cells, downregulation of this protein by $8 \mathrm{~b}$ might prevent apoptosis in these cells (Keng et al. 2006).

\subsection{Conclusion}

As described in this chapter, SARS-CoV structural and accessory proteins are potent inducers and modulators of apoptosis in vitro. Structural proteins mainly trigger the intrinsic apoptotic pathway, with p38 MAPK and PI3K/Akt pathways regulating cell death. Expression of accessory proteins leads to apoptosis by more diverse routes, involving various possibilities even for the same protein to induce cell death. However, one has to note that these observations were mostly obtained by cell culture experiments and might differ from effects in vivo. Whether the proteins are able to induce necrosis remains to be elucidated, although necrosis is assumed to be the underlying mechanism for the extensive immune overreaction and massive inflammation observed during clinical SARS-CoV infection. Induction of cell death might furthermore be modulated by the interplay of viral and host cell proteins, as exemplified for the $\mathrm{N}$ protein. In addition, it has to be assumed that one structural or accessory protein may not be solely responsible for induction or modulation of cell death but rather that the orchestrated activity of all viral proteins expressed at a certain time point finally results in the exquisite virulence and pathogenesis throughout infection with SARS-CoV.

\section{References}

Abreu MT, Arnold ET, Chow JY, Barrett KE (2001) Phosphatidylinositol 3-kinase-dependent pathways oppose Fas-induced apoptosis and limit chloride secretion in human intestinal epithelial cells. Implications for inflammatory diarrheal states. J Biol Chem 276:47563-47574

Akerstrom S, Mirazimi A, Tan YJ (2007) Inhibition of SARS-CoV replication cycle by small interference RNAs silencing specific SARS proteins, 7a/7b, 3a/3b and S. Antiviral Res 73: 219-227

An S, Chen CJ, Yu X, Leibowitz JL, Makino S (1999) Induction of apoptosis in murine coronavirus-infected cultured cells and demonstration of $\mathrm{E}$ protein as an apoptosis inducer. J Virol 73:7853-7859

Booth CM, Matukas LM, Tomlinson GA, Rachlis AR, Rose DB, Dwosh HA, Walmsley SL, Mazzulli T, Avendano M, Derkach P, Ephtimios IE, Kitai I, Mederski BD, Shadowitz SB, Gold WL, Hawryluck LA, Rea E, Chenkin JS, Cescon DW, Poutanen SM, Detsky AS (2003) Clinical features and short-term outcomes of 144 patients with SARS in the greater Toronto area. JAMA 289:2801-2809

Bordi L, Castilletti C, Falasca L, Ciccosanti F, Calcaterra S, Rozera G, Di Caro A, Zaniratti S, Rinaldi A, Ippolito G, Piacentini M, Capobianchi MR (2006) Bcl-2 inhibits the caspase-dependent 
apoptosis induced by SARS-CoV without affecting virus replication kinetics. Arch Virol 151: 369-377

Cantrell DA (2001) Phosphoinositide 3-kinase signalling pathways. J Cell Sci 114:1439-1445

Chan WS, Wu C, Chow SC, Cheung T, To KF, Leung WK, Chan PK, Lee KC, Ng HK, Au DM, Lo AW (2005) Coronaviral hypothetical and structural proteins were found in the intestinal surface enterocytes and pneumocytes of severe acute respiratory syndrome (SARS). Mod Pathol 18:1432-1439

Chan CP, Siu KL, Chin KT, Yuen KY, Zheng B, Jin DY (2006) Modulation of the unfolded protein response by the severe acute respiratory syndrome coronavirus spike protein. J Virol 80:9279-9287

Chan CM, Ma CW, Chan WY, Chan HY (2007) The SARS-Coronavirus Membrane protein induces apoptosis through modulating the Akt survival pathway. Arch Biochem Biophys 459:197-207

Chen YY, Shuang B, Tan YX, Meng MJ, Han P, Mo XN, Song QS, Qiu XY, Luo X, Gan QN, Zhang X, Zheng Y, Liu SA, Wang XN, Zhong NS, Ma DL (2005) The protein X4 of severe acute respiratory syndrome-associated coronavirus is expressed on both virus-infected cells and lung tissue of severe acute respiratory syndrome patients and inhibits growth of Balb/c 3T3 cell line. Chin Med J 118:267-274

Chen CY, Ping YH, Lee HC, Chen KH, Lee YM, Chan YJ, Lien TC, Jap TS, Lin CH, Kao LS, Chen YM (2007) Open reading frame 8a of the human severe acute respiratory syndrome coronavirus not only promotes viral replication but also induces apoptosis. J Infect Dis 196:405-415

Chow KY, Yeung YS, Hon CC, Zeng F, Law KM, Leung FC (2005) Adenovirus-mediated expression of the C-terminal domain of SARS-CoV spike protein is sufficient to induce apoptosis in Vero E6 cells. FEBS Lett 579:6699-6704

Cinatl J Jr, Hoever G, Morgenstern B, Preiser W, Vogel JU, Hofmann WK, Bauer G, Michaelis M, Rabenau HF, Doerr HW (2004) Infection of cultured intestinal epithelial cells with severe acute respiratory syndrome coronavirus. Cell Mol Life Sci 61:2100-2112

Diemer C, Schneider M, Seebach J, Quaas J, Frosner G, Schatzl HM, Gilch S (2008) Cell typespecific cleavage of nucleocapsid protein by effector caspases during SARS coronavirus infection. J Mol Biol 376:23-34

Fielding BC, Tan YJ, Shuo S, Tan TH, Ooi EE, Lim SG, Hong W, Goh PY (2004) Characterization of a unique group-specific protein (U122) of the severe acute respiratory syndrome coronavirus. J Virol 78:7311-7318

Frieman M, Yount B, Heise M, Kopecky-Bromberg SA, Palese P, Baric RS (2007) Severe acute respiratory syndrome coronavirus ORF6 antagonizes STAT1 function by sequestering nuclear import factors on the rough endoplasmic reticulum/Golgi membrane. J Virol 81:9812-9824

Gauthier R, Harnois C, Drolet JF, Reed JC, Vezina A, Vachon PH (2001) Human intestinal epithelial cell survival: differentiation state-specific control mechanisms. Am J Physiol Cell Physiol 280:C1540-C1554

Geng H, Liu YM, Chan WS, Lo AW, Au DM, Waye MM, Ho YY (2005) The putative protein 6 of the severe acute respiratory syndrome-associated coronavirus: expression and functional characterization. FEBS Lett 579:6763-6768

Green DR (2000) Apoptotic pathways: paper wraps stone blunts scissors. Cell 102:1-4

Guan Y, Zheng BJ, He YQ, Liu XL, Zhuang ZX, Cheung CL, Luo SW, Li PH, Zhang LJ, Guan YJ, Butt KM, Wong KL, Chan KW, Lim W, Shortridge KF, Yuen KY, Peiris JS, Poon LL (2003) Isolation and characterization of viruses related to the SARS coronavirus from animals in southern China. Science 302:276-278

Guo Y, Korteweg C, McNutt MA, Gu J (2008) Pathogenetic mechanisms of severe acute respiratory syndrome. Virus Res 133:4-12

He R, Leeson A, Ballantine M, Andonov A, Baker L, Dobie F, Li Y, Bastien N, Feldmann H, Strocher U, Theriault S, Cutts T, Cao J, Booth TF, Plummer FA, Tyler S, Li X (2004) Characterization of protein-protein interactions between the nucleocapsid protein and membrane protein of the SARS coronavirus. Virus Res 105:121-125 
Huang C, Ito N, Tseng CT, Makino S (2006a) Severe acute respiratory syndrome coronavirus 7a accessory protein is a viral structural protein. J Virol 80:7287-7294

Huang C, Narayanan K, Ito N, Peters CJ, Makino S (2006b) Severe acute respiratory syndrome coronavirus 3 a protein is released in membranous structures from 3 a protein-expressing cells and infected cells. J Virol 80:210-217

Huang C, Peters CJ, Makino S (2007) Severe acute respiratory syndrome coronavirus accessory protein 6 is a virion-associated protein and is released from 6 protein-expressing cells. J Virol 81:5423-5426

Ito N, Mossel EC, Narayanan K, Popov VL, Huang C, Inoue T, Peters CJ, Makino S (2005) Severe acute respiratory syndrome coronavirus 3 a protein is a viral structural protein. J Virol 79:3182-3186

Kanzawa N, Nishigaki K, Hayashi T, Ishii Y, Furukawa S, Niiro A, Yasui F, Kohara M, Morita K, Matsushima K, Le MQ, Masuda T, Kannagi M (2006) Augmentation of chemokine production by severe acute respiratory syndrome coronavirus $3 \mathrm{a} / \mathrm{X} 1$ and $7 \mathrm{a} / \mathrm{X} 4$ proteins through NF-kappaB activation. FEBS Lett 580:6807-6812

Keng CT, Choi YW, Welkers MR, Chan DZ, Shen S, Gee LS, Hong W, Tan YJ (2006) The human severe acute respiratory syndrome coronavirus (SARS-CoV) $8 \mathrm{~b}$ protein is distinct from its counterpart in animal SARS-CoV and down-regulates the expression of the envelope protein in infected cells. Virology 354(1):132-142

Khan S, Fielding BC, Tan TH, Chou CF, Shen S, Lim SG, Hong W, Tan YJ (2006) Overexpression of severe acute respiratory syndrome coronavirus $3 \mathrm{~b}$ protein induces both apoptosis and necrosis in Vero E6 cells. Virus Res 122(1-2):20-27

Kopecky-Bromberg SA, Martinez-Sobrido L, Palese P (2006) 7a protein of severe acute respiratory syndrome coronavirus inhibits cellular protein synthesis and activates p38 mitogenactivated protein kinase. J Virol 80:785-793

Kopecky-Bromberg SA, Martinez-Sobrido L, Frieman M, Baric RA, Palese P (2007) Severe acute respiratory syndrome coronavirus open reading frame (ORF) 3b, ORF 6, and nucleocapsid proteins function as interferon antagonists. J Virol 81:548-557

Kulik G, Klippel A, Weber MJ (1997) Antiapoptotic signalling by the insulin-like growth factor I receptor, phosphatidylinositol 3-kinase, and Akt. Mol Cell Biol 17:1595-1606

Lai CW, Chan ZR, Yang DG, Lo WH, Lai YK, Chang MD, Hu YC (2006) Accelerated induction of apoptosis in insect cells by baculovirus-expressed SARS-CoV membrane protein. FEBS Lett 580:3829-3834

Law PT, Wong CH, Au TC, Chuck CP, Kong SK, Chan PK, To KF, Lo AW, Chan JY, Suen YK, Chan HY, Fung KP, Waye MM, Sung JJ, Lo YM, Tsui SK (2005) The 3a protein of severe acute respiratory syndrome-associated coronavirus induces apoptosis in Vero E6 cells. J Gen Virol 86:1921-1930

Law PY, Liu YM, Geng H, Kwan KH, Waye MM, Ho YY (2006) Expression and functional characterization of the putative protein $8 \mathrm{~b}$ of the severe acute respiratory syndrome-associated coronavirus. FEBS Lett 580:3643-3648

Liu C, Xu HY, Liu DX (2001) Induction of caspase-dependent apoptosis in cultured cells by the avian coronavirus infectious bronchitis virus. J Virol 75:6402-6409

Lu W, Zheng BJ, Xu K, Schwarz W, Du L, Wong CK, Chen J, Duan S, Deubel V, Sun B (2006) Severe acute respiratory syndrome-associated coronavirus 3a protein forms an ion channel and modulates virus release. Proc Natl Acad Sci USA 103:12540-12545

Marra MA, Jones SJ, Astell CR, Holt RA, Brooks-Wilson A, Butterfield YS, Khattra J, Asano JK, Barber SA, Chan SY, Cloutier A, Coughlin SM, Freeman D, Girn N, Griffith OL, Leach SR, Mayo M, McDonald H, Montgomery SB, Pandoh PK, Petrescu AS, Robertson AG, Schein JE, Siddiqui A, Smailus DE, Stott JM, Yang GS, Plummer F, Andonov A, Artsob H, Bastien N, Bernard K, Booth TF, Bowness D, Czub M, Drebot M, Fernando L, Flick R, Garbutt M, Gray M, Grolla A, Jones S, Feldmann H, Meyers A, Kabani A, Li Y, Normand S, Stroher U, Tipples GA, Tyler S, Vogrig R, Ward D, Watson B, Brunham RC, Krajden M, Petric M, Skowronski DM, Upton C, Roper RL (2003) The genome sequence of the SARS-associated coronavirus. Science 300:1399-1404 
Mizutani T, Fukushi S, Saijo M, Kurane I, Morikawa S (2004a) Importance of Akt signaling pathway for apoptosis in SARS-CoV-infected Vero E6 cells. Virology 327:169-174

Mizutani T, Fukushi S, Saijo M, Kurane I, Morikawa S (2004b) Phosphorylation of p38 MAPK and its downstream targets in SARS coronavirus-infected cells. Biochem Biophys Res Commun 319:1228-1234

Mizutani T, Fukushi S, Saijo M, Kurane I, Morikawa S (2005) JNK and PI3k/Akt signaling pathways are required for establishing persistent SARS-CoV infection in Vero E6 cells. Biochim Biophys Acta 1741:4-10

Nelson CA, Pekosz A, Lee CA, Diamond MS, Fremont DH (2005) Structure and intracellular targeting of the SARS-coronavirus Orf7a accessory protein. Structure 13:75-85

Nicholls JM, Poon LL, Lee KC, Ng WF, Lai ST, Leung CY, Chu CM, Hui PK, Mak KL, Lim W, Yan KW, Chan KH, Tsang NC, Guan Y, Yuen KY, Peiris JS (2003) Lung pathology of fatal severe acute respiratory syndrome. Lancet 361:1773-1778

Nicholls JM, Butany J, Poon LL, Chan KH, Beh SL, Poutanen S, Peiris JS, Wong M (2006) Time course and cellular localization of SARS-CoV nucleoprotein and RNA in lungs from fatal cases of SARS. PLoS Med 3:e27

Padhan K, Minakshi R, Towheed MA, Jameel S (2008) Severe acute respiratory syndrome coronavirus 3 a protein activates the mitochondrial death pathway through p38 MAP kinase activation. J Gen Virol 89:1960-1969

Pewe L, Zhou H, Netland J, Tangudu C, Olivares H, Shi L, Look D, Gallagher T, Perlman S (2005) A severe acute respiratory syndrome-associated coronavirus-specific protein enhances virulence of an attenuated murine coronavirus. J Virol 79:11335-11342

Ren L, Yang R, Guo L, Qu J, Wang J, Hung T (2005) Apoptosis induced by the SARS-associated coronavirus in Vero cells is replication-dependent and involves caspase. DNA Cell Biol 24:496-502

Schaecher SR, Touchette E, Schriewer J, Buller RM, Pekosz A (2007) Severe acute respiratory syndrome coronavirus gene 7 products contribute to virus-induced apoptosis. J Virol 81: 11054-11068

Shen S, Lin PS, Chao YC, Zhang A, Yang X, Lim SG, Hong W, Tan YJ (2005) The severe acute respiratory syndrome coronavirus $3 \mathrm{a}$ is a novel structural protein. Biochem Biophys Res Commun 330:286-292

Surjit M, Liu B, Jameel S, Chow VT, Lal SK (2004) The SARS coronavirus nucleocapsid protein induces actin reorganization and apoptosis in COS-1 cells in the absence of growth factors. Biochem J 383:13-18

Tan YJ, Fielding BC, Goh PY, Shen S, Tan TH, Lim SG, Hong W (2004a) Overexpression of 7a, a protein specifically encoded by the severe acute respiratory syndrome coronavirus, induces apoptosis via a caspase-dependent pathway. J Virol 78:14043-14047

Tan YJ, Teng E, Shen S, Tan TH, Goh PY, Fielding BC, Ooi EE, Tan HC, Lim SG, Hong W (2004b) A novel severe acute respiratory syndrome coronavirus protein, U274, is transported to the cell surface and undergoes endocytosis. J Virol 78:6723-6734

Tan YJ, Tham PY, Chan DZ, Chou CF, Shen S, Fielding BC, Tan TH, Lim SG, Hong W (2005) The severe acute respiratory syndrome coronavirus $3 \mathrm{a}$ protein up-regulates expression of fibrinogen in lung epithelial cells. J Virol 79:10083-10087

Tan YX, Tan TH, Lee MJ, Tham PY, Gunalan V, Druce J, Birch C, Catton M, Fu NY, Yu VC, Tan YJ (2007) Induction of apoptosis by the severe acute respiratory syndrome coronavirus $7 \mathrm{a}$ protein is dependent on its interaction with the Bcl-XL protein. J Virol 81:6346-6355

Yan H, Xiao G, Zhang J, Hu Y, Yuan F, Cole DK, Zheng C, Gao GF (2004) SARS coronavirus induces apoptosis in Vero E6 cells. J Med Virol 73:323-331

Yang M, Li CK, Li K, Hon KL, Ng MH, Chan PK, Fok TF (2004) Hematological findings in SARS patients and possible mechanisms (review). Int J Mol Med 14:311-315

Yang Y, Xiong Z, Zhang S, Yan Y, Nguyen J, Ng B, Lu H, Brendese J, Yang F, Wang H, Yang XF (2005) Bcl-xL inhibits T-cell apoptosis induced by expression of SARS coronavirus E protein in the absence of growth factors. Biochem J 392:135-143 
Ye Z, Wong CK, Li P, Xie Y (2008) A SARS-CoV protein, ORF-6, induces caspase-3 mediated, ER stress and JNK-dependent apoptosis. Biochim Biophys Acta 1780(12):1383-1387

Yeung YS, Yip CW, Hon CC, Chow KY, Ma IC, Zeng F, Leung FC (2008) Transcriptional profiling of Vero E6 cells over-expressing SARS-CoV S2 subunit: insights on viral regulation of apoptosis and proliferation. Virology 371:32-43

Ying W, Hao Y, Zhang Y, Peng W, Qin E, Cai Y, Wei K, Wang J, Chang G, Sun W, Dai S, Li X, Zhu Y, Li J, Wu S, Guo L, Dai J, Wang J, Wan P, Chen T, Du C, Li D, Wan J, Kuai X, Li W, Shi R, Wei H, Cao C, Yu M, Liu H, Dong F, Wang D, Zhang X, Qian X, Zhu Q, He F (2004) Proteomic analysis on structural proteins of Severe Acute Respiratory Syndrome coronavirus. Proteomics 4:492-504

Yount B, Roberts RS, Sims AC, Deming D, Frieman MB, Sparks J, Denison MR, Davis N, Baric RS (2005) Severe acute respiratory syndrome coronavirus group-specific open reading frames encode nonessential functions for replication in cell cultures and mice. J Virol 79: $14909-14922$

Yu CJ, Chen YC, Hsiao CH, Kuo TC, Chang SC, Lu CY, Wei WC, Lee CH, Huang LM, Chang MF, Ho HN, Lee FJ (2004) Identification of a novel protein 3a from severe acute respiratory syndrome coronavirus. FEBS Lett 565:111-116

Yuan X, Li J, Shan Y, Yang Z, Zhao Z, Chen B, Yao Z, Dong B, Wang S, Chen J, Cong Y (2005a) Subcellular localization and membrane association of SARS-CoV 3a protein. Virus Res 109:191-202

Yuan X, Shan Y, Zhao Z, Chen J, Cong Y (2005b) G0/G1 arrest and apoptosis induced by SARSCoV $3 b$ protein in transfected cells. Virol J 2:66

Yuan X, Yao Z, Shan Y, Chen B, Yang Z, Wu J, Zhao Z, Chen J, Cong Y (2005c) Nucleolar localization of non-structural protein $3 \mathrm{~b}$, a protein specifically encoded by the severe acute respiratory syndrome coronavirus. Virus Res 114:70-79

Yuan X, Wu J, Shan Y, Yao Z, Dong B, Chen B, Zhao Z, Wang S, Chen J, Cong Y (2006) SARS coronavirus 7a protein blocks cell cycle progression at G0/G1 phase via the cyclin D3/pRb pathway. Virology 346:74-85

Yuan X, Yao Z, Wu J, Zhou Y, Shan Y, Dong B, Zhao Z, Hua P, Chen J, Cong Y (2007) G1 phase cell cycle arrest induced by SARS-CoV 3a protein via the cyclin D3/pRb pathway. Am J Respir Cell Mol Biol 37:9-19

Zeng R, Yang RF, Shi MD, Jiang MR, Xie YH, Ruan HQ, Jiang XS, Shi L, Zhou H, Zhang L, Wu XD, Lin Y, Ji YY, Xiong L, Jin Y, Dai EH, Wang XY, Si BY, Wang J, Wang HX, Wang CE, Gan YH, Li YC, Cao JT, Zuo JP, Shan SF, Xie E, Chen SH, Jiang ZQ, Zhang X, Wang Y, Pei G, Sun B, Wu JR (2004) Characterization of the 3a protein of SARS-associated coronavirus in infected vero E6 cells and SARS patients. J Mol Biol 341:271-279

Zhang QL, Ding YQ, He L, Wang W, Zhang JH, Wang HJ, Cai JJ, Geng J, Lu YD, Luo YL (2003) Detection of cell apoptosis in the pathological tissues of patients with SARS and its significance. Di Yi Jun Yi Da Xue Xue Bao 23:770-773

Zhang L, Wei L, Jiang D, Wang J, Cong X, Fei R (2007) SARS-CoV nucleocapsid protein induced apoptosis of COS-1 mediated by the mitochondrial pathway. Artif Cells Blood Substit Immobil Biotechnol 35:237-253

Zhao G, Shi SQ, Yang Y, Peng JP (2006) M and N proteins of SARS coronavirus induce apoptosis in HPF cells. Cell Biol Toxicol 22:313-322

Zhao X, Nicholls JM, Chen YG (2008) Severe acute respiratory syndrome-associated coronavirus nucleocapsid protein interacts with Smad3 and modulates transforming growth factor-beta signaling. J Biol Chem 283:3272-3280 